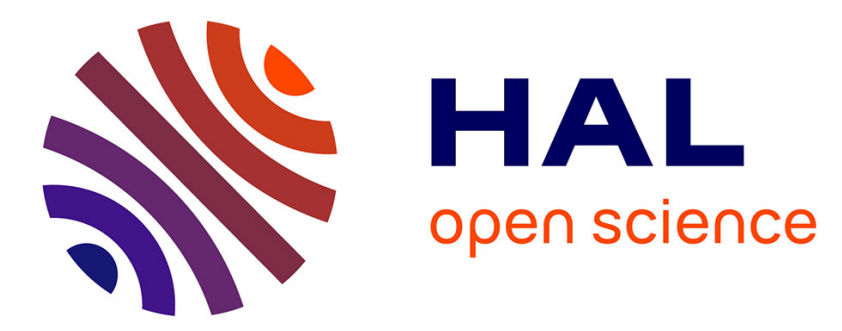

\title{
Effects of vegetation patterns on yields of the surface and subsurface waters in the Heishui Alpine Valley in west China
}

Yehan Liu, S. An, Z. Deng, N. Fan, H. Yang, Z. Wang, Y. Zhi, C. Zhou, S. Liu

\section{- To cite this version:}

Yehan Liu, S. An, Z. Deng, N. Fan, H. Yang, et al.. Effects of vegetation patterns on yields of the surface and subsurface waters in the Heishui Alpine Valley in west China. Hydrology and Earth System Sciences Discussions, 2006, 3 (3), pp.1021-1043. hal-00298709

\section{HAL Id: hal-00298709 \\ https://hal.science/hal-00298709}

Submitted on 16 Jun 2006

HAL is a multi-disciplinary open access archive for the deposit and dissemination of scientific research documents, whether they are published or not. The documents may come from teaching and research institutions in France or abroad, or from public or private research centers.
L'archive ouverte pluridisciplinaire HAL, est destinée au dépôt et à la diffusion de documents scientifiques de niveau recherche, publiés ou non, émanant des établissements d'enseignement et de recherche français ou étrangers, des laboratoires publics ou privés. 
Hydrol. Earth Syst. Sci. Discuss., 3, 1021-1043, 2006 www.hydrol-earth-syst-sci-discuss.net/3/1021/2006/

(C) Author(s) 2006. This work is licensed under a Creative Commons License.
Hydrology and Earth System Sciences Discussions

Papers published in Hydrology and Earth System Sciences Discussions are under open-access review for the journal Hydrology and Earth System Sciences

\section{Effects of vegetation patterns on yields of the surface and subsurface waters in the Heishui Alpine Valley in west China}

Y. Liu ${ }^{1}$, S. An ${ }^{1}$, Z. Deng ${ }^{1}$, N. Fan ${ }^{1}$, H. Yang ${ }^{1}$, Z. Wang ${ }^{1}$, Y. Zhi ${ }^{1}$, C. Zhou ${ }^{1}$, and S. Liu $^{2}$

${ }^{1}$ Laboratory of Forest Ecology and Global Changes, School of Life Sciences, Nanjing University, Nanjing 210093, China

${ }^{2}$ Institute of Forest Ecology, Environment and Protection, the Chinese Academy of Forestry, Beijing 100091, China

Received: 22 March 2006 - Accepted: 19 April 2006 - Published: 16 June 2006

Correspondence to: S. An (anshq@nju.edu.cn)

Effects of vegetation patterns on yields of water

Y. Liu et al.

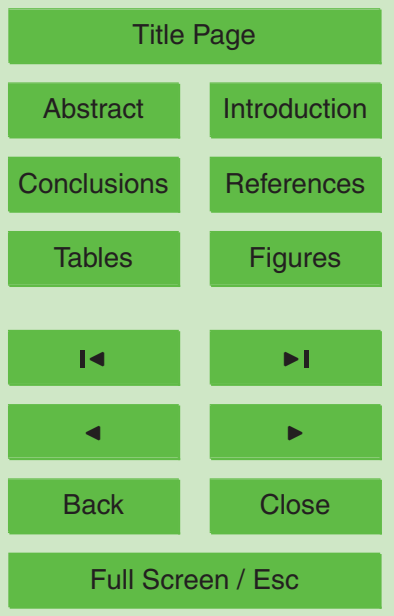

Printer-friendly Version

Interactive Discussion 


\section{Abstract}

The relationships between different vegetation types and water yields were investigated in the Heishui Valley of the upper Yangtze River in western China. Contributions of groundwater and the water from surface and subsurface in different tributaries were, 5 respectively, computed based on the stable isotope data, while the percentages of different vegetation covers were achieved by remote sensing in landscape scale. Based on the relationships between different vegetation types and water yields in seven watersheds, we found that reduction in the total vegetation, forest and subalpine coniferous forest covers could cause increasing in surface and subsurface water yields, while the All the relationships were displayed as the low altitude and high altitude patterns, which were caused by the different vegetation characteristics and topography. We also found effects of the total vegetation cover played the most important role on water yield at large scale while the coniferous forest cover would affect the water yield at relatively 15 small scale.

\section{Introduction}

Water and vegetation are the important resources on earth and the main components of the ecosystems. In general, hydrological behaviors affect key ecosystem processes and the effects depend on the amounts and duration of water storage in vegetation canopies, soils and stream channels (Post and Jones, 2001). So it is important to study the relationships between water and vegetation in hydrological cycle aspect, especially that between the forest and hydrology.

On the effects of vegetation on hydrological traits, many studies have been carried out in paired-watershed. Hibbert (1967) reviewed 39 experimental catchments and concluded that the reduction in forest cover increased water yield; Bosch and Hewlett (1982) summarized 94 experimental catchments and believed that different vegetation

\section{HESSD}

3, 1021-1043, 2006

Effects of vegetation patterns on yields of water

Y. Liu et al.

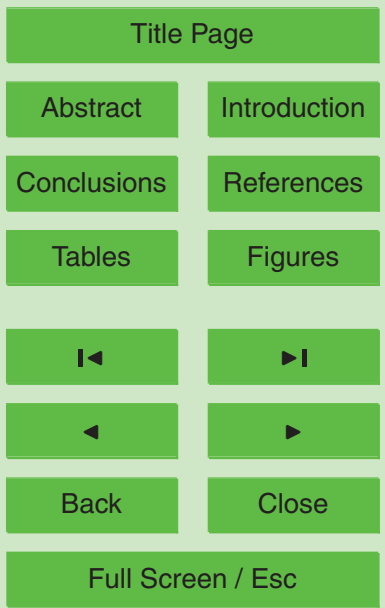

Printer-friendly Version

Interactive Discussion 
types, such as coniferous forests and deciduous hardwoods, caused different variations in annual water yield; and then Sahin and Hall (1996) drawn a similar conclusion according to their reviews of 145 experimental catchments. But most of these experimental catchments are smaller than $2 \mathrm{~km}^{2}$ (Andreassian, 2004) and the results needed 5 scaling to and verifying in the larger catchments (Brown et al., 2005).

In the studies of hydrological cycles, the stable isotope $\mathrm{H}$ was used to identify the water sources and their contributions (Leopoldo et al., 1987; McDonnel et al., 1991; Kendall, 1993; Mortathi et al., 1997). For example, McDonnel et al. (1991) found that stream water in New Zealand was supplied partially by subsurface flow in the humid 10 zone, while Mortathi et al. (1997) reported that the average contributions of surface runoff and base flow (pre-event) were $30.3 \%$ and $69.7 \%$, respectively, in the Amazon River. But, most researches also focus on hydrological behaviors in small catchments and there are few researches at large scale.

Remote sensing has many applications in hydrology, which included monitoring the 15 surface extents of water bodies, water vapor, snow and ices, and water quality (Jiang et al., 2004). And there are also many additional applications of remote sensing in hydrological process, such as hydrologic watershed assessment, reservoir site selection, fish habitat survey, floodplain and shoreline zoning compliance, and survey of recreational use of lakes and rivers (Lillesand and Kiefer, 2000). However, the researches of hydrological process mainly focus on the physical aspects, and the interaction between hydrological traits and vegetations was still poorly understood at large scale (Barrent and Curtis, 1999; Chang, 2003). Thus, it is useful to use remote sensing to study the effects of vegetation on hydrological process at large scale.

From the mentions above we know that there are few researches on effects of vegetation on hydrological process by the combination of the stable isotope and remote sense techniques on large scale. More studies based on the combination technique of stable isotope tracing and remote sensing are necessary.

The Heishui Valley, one of upper catchment in Yangtze River, is the most important conjunction region between eastern and western $\mathrm{China}$, and the region is both a great
HESSD

3, 1021-1043, 2006

Effects of vegetation patterns on yields of water

Y. Liu et al.

Title Page

Abstract

Introduction

Conclusions

Tables

References

Figures

14

$\rightarrow 1$

4

Back

Close

Full Screen / Esc

Printer-friendly Version

Interactive Discussion 
potential place for economic development and one of the most sensitive ecological and environmental areas in China (Chen, 2000). If the ecological environment of the upper course of the Yangtze River is destroyed, it will postpone the economic development of most of western China, and will lead to the flooding of the middle and lower courses 5 of the river (Liu et al., 2001). So it is urgently needed to study effects of vegetation on hydrological process in this region at a relatively large scale.

In this study, we computed the contributions of different tributary waters based on the stable isotope $\mathrm{H}$ tracers, classified the vegetation types of different watersheds using remote sense technique, and tried to find how the different vegetation patterns 10 affect the hydrology variation on large watershed scale during transitional period from low-flow to high-flow in the Heishui Valley.

\section{Study areas}

The Minjiang River, originating in the Gonggang Mountain, is an important tributary feeding the upper course of the Yangtze River, China. The upper course of the Minjiang 15 River, about $24000 \mathrm{~km}^{2}$ in area, is the transitional area between the Tebiet Plateau and the Sichuan Basin (Pu, 2000; Li et al., 2003). The Heishui Valley (River) $\left(102^{\circ} 36^{\prime}-\right.$ $103^{\circ} 30^{\prime} \mathrm{E}, 31^{\circ} 53^{\prime}-32^{\circ} 38^{\prime} \mathrm{N}$ ), including its western waters originating from the Yanggong Mountain and its northern waters originating from the Maoergai Grasslands, is the largest tributary of the upper course of the Minjiang River in western Sichuan Province 20 (Fig. 1). The Heishui valley covers $7240 \mathrm{~km}^{2}$ and occupies $31.4 \%$ of the total area of the upper Minjiang River. The main tributary of the Heishui River is $122 \mathrm{~km}$ long, and includes $1048 \mathrm{~m}$ of falls from Maoergai Grasslands to Shaba Village (Wang, 2003).

In the Heishui valley, the average annual temperature is $9^{\circ} \mathrm{C}$, and the average annual rainfall is $833 \mathrm{~mm}$. The climate type is a monsoon climate, and there are obvious differences between the wet season (May through October) and the dry season (November through April) (Zhang et al., 2002).

There are complex topographs in the region (Fig. 2), and there are also obvious alti-

\section{HESSD}

3, 1021-1043, 2006

Effects of vegetation patterns on yields of water

Y. Liu et al.

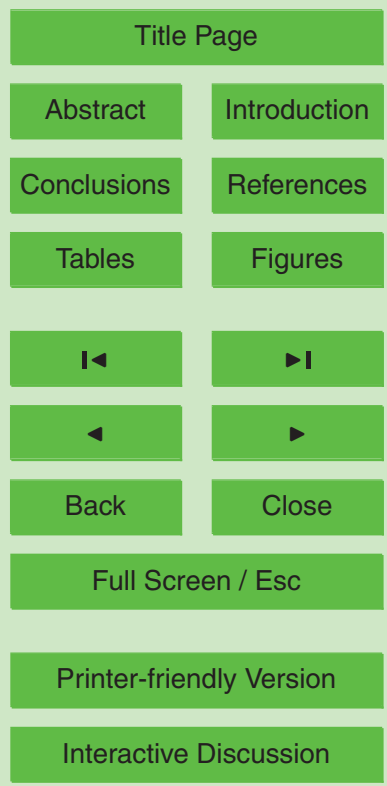

EGU 
tudinal belts holding the various soil types (Zhang et al., 2002; Chen et al., 2003). Alluvial soil and mountain gray cinnamon soil are distributed between $1900 \mathrm{~m}$ and $2400 \mathrm{~m}$, mountain cinnamon soil is distributed between $2400 \mathrm{~m}$ and $2900 \mathrm{~m}$, mountain brown forest soil is distributed between $2900 \mathrm{~m}$ and $4000 \mathrm{~m}$, alpine meadow soil is distributed 5 between $4000 \mathrm{~m}$ and $4500 \mathrm{~m}$, and alpine forest desert soil is distributed above $4500 \mathrm{~m}$.

There are eight natural distinct vegetation types distributed along various altitudes in the Heishui valley (Jiang, 1994; Zhuang et al., 1995; Zhang et al., 2002; Jiang et al., 2004). The vegetation types include: (1) Arid shrub, whose latitude of distribution lies between $2300 \mathrm{~m}$ and $2400 \mathrm{~m}$. Within these shrublands, the dominant species are 10 Aophora viciifolia, Cotinus coggvria and Lucium chinense. (2) Deciduous broadleaved forest, distributed at latitudes between $2400 \mathrm{~m}$ and $2600 \mathrm{~m}$. The dominant species in this region are Quercus liaotungensis and betula davurica. (3) Mixed broadleaf and coniferous forest, distributed at latitudes between $2600 \mathrm{~m}$ and $2900 \mathrm{~m}$. The dominant species here include Picea asperata, Pimus tabulaeformis and Quercus liaotungensis.

15 (4) Subalpine coniferous forest, distributed between $2900 \mathrm{~m}$ and $3800 \mathrm{~m}$. This area's dominant species are Abies fabric and Picea asperata. (5) Alpine shrub, distributed between $2600 \mathrm{~m}$ and $3600 \mathrm{~m}$. The dominant species here include Spiraea alpina and Lonicera litangensis. (6) Alpine shrub meadow, distributed above $3600 \mathrm{~m}$. The dominant species include Carex alpine and Salixspp. (7) Alpine meadow, distributed between $4000 \mathrm{~m}$ and $4500 \mathrm{~m}$. The dominant species in this thinning area are Kobresiap ygmaea and Carex alpine. And (8) Hillside and mountaintop, they distributed above $4500 \mathrm{~m}$. Here, there are few herbaceous plants or fruting plants.

\section{Methods}

\subsection{Field sampling}

25 Water sampling sites for the river are presented in Fig. 3. There were 13 sampling sites chosen within the junction of the river's principal course and its tributaries. The
HESSD

3, 1021-1043, 2006

Effects of vegetation patterns on yields of water

Y. Liu et al.

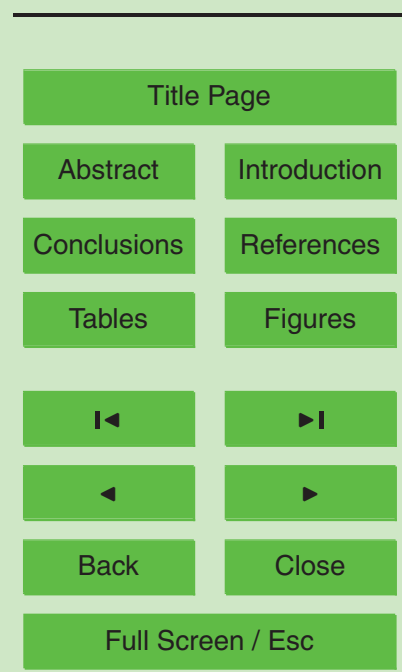

Printer-friendly Version

Interactive Discussion 
sampling sites were named $C, D, G, L$ and $M$ along the principal course, and $A, B$, $\mathrm{E}, \mathrm{F}, \mathrm{H}, \mathrm{I}, \mathrm{J}$ and $\mathrm{K}$ for samples taken along the tributaries. At each sampling site water samples were collected at 08:00 a.m., 12:00 noon and 04:00 p.m. each day, and this regime was repeated for a total of three collection days. A total of 117 samples 5 were collected during a level-flow period. All water samples were collected by water collectors and stored in $250 \mathrm{ml}$ non-reactive plastic bottles with rubber-seal caps. The sampling window ran from 3 June through 5 June, technically during the humid season, which began the next day after the rain was over. The reason for selecting this window was that the direct effects of rain and its surface water on the river as a whole were eliminated, according to stable curves of water levels noted by the hydrology station of the Heishui County. The same methods were used during the low-flow period, whose sampling times included 19 March through 30 March, 31 through 2 April, and 5 April through 8 during the dry season in 2004.

\subsection{Measurement of $\delta \mathrm{D}$}

15 The measurement and analysis of water samples was completed using the Thermal Finnigan MAT DelTaplus XP. Accuracy of the measurements was $\pm 3 \%$ o for $\delta \mathrm{D}$. The final results were expressed by the relative to the value over SMOW: $\delta \mathrm{D}=\left[(\mathrm{D} / \mathrm{H})_{\text {sample }}-(\mathrm{D} / \mathrm{H})_{\mathrm{SMOW}}\right] /(\mathrm{D} / \mathrm{H})_{\mathrm{SMOW}} \times 10^{3}$.

\subsection{Methods of computing the contributions of different watersheds}

Proportional contributions of several water sources to the mixed during a given period of level flow were computed by the methods of the stable isotope $\mathrm{H}$. In the analysis of contributions, a two-component model (Pinder and Jones, 1969) and IsoSource model (Phillips and Cregg, 2003), as described below, was, respectively, used:

Two-component model was used to cope with one isotope system with two sources:
$Q_{t} \times C_{t}=Q_{s} \times C_{s}+Q_{p} \times C_{p}$
HESSD

3, 1021-1043, 2006

Effects of vegetation patterns on yields of water

Y. Liu et al.

Title Page

Abstract

Introduction

Conclusions

Tables

References

Figures

14

$>1$

4

Back

Close

Full Screen / Esc

Printer-friendly Version

Interactive Discussion 
$Q_{s}+Q_{p}=Q_{t}$

$Q$ was the discharge, C was the concentration of the applicable tracer, and the subscripts $t, s$ and $p$ referred to total, event, and pre-event water components, respectively.

IsoSource model in this study was used to cope with one isotope system with three 5 sources:

$\delta_{M}=f_{A} \times \delta_{A}+f_{B} \times \delta_{B}+f_{C} \times \delta_{C}$

$1=f_{A}+f_{B}+f_{C}$

$f$ was the proportions of source, $\delta_{A}, \delta_{B}$ and $\delta_{C}$ were the source isotope signature and $\delta_{M}$ was the observed isotope signature of the mixed.

10 The equations were suitable for three sources and the IsoSource model was also performed in $n$ isotope systems and $>n+1$ soueces. And in this study an average proportional contributions were used.

Hydrological data were collected in the two hydrological monitor stations (Fig. 3), and the contributions of different sources computed by the stable isotope method were tested by the results of data of runoff amount.

\subsection{Vegetation classification with remotely sensed data}

This study was based on the classification of Landsat $7 \mathrm{TM}$ satellite image acquired on 10 July 2002 (path 130, row 38). The projection system in the satellite image was Universal Transverse Mercator (UTM) zone 50, and the spheroid and datum were 20 Clarke 1866. ERDAS imagine software version 8.6 and ARCMAP GIS software version 8.3 were used to carry out the classification and mapping tasks.

In the classification of satellite image of the Heishui valley, the optimal iterative unsupervised classification (OIUC) method was used (Jiang et al., 2004). The OIUC method mainly includes that development of reference datasets, optimal iterative classification using ISODATA clustering and post-classification treatment. The accuracy of

Effects of vegetation patterns on yields of water

Y. Liu et al.

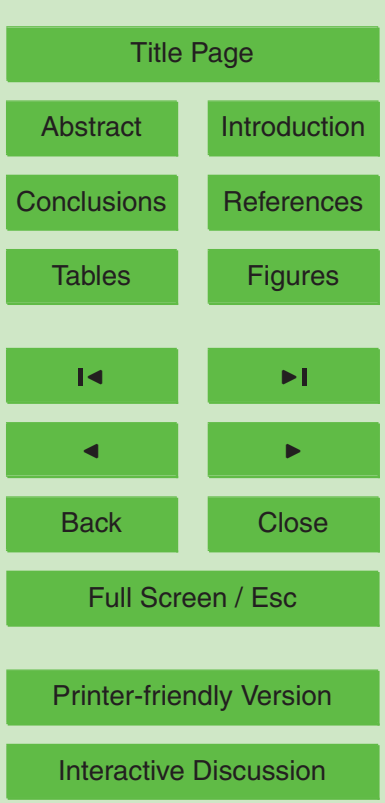

EGU 
the vegetation classification in the Heishui valley was assessed by field validation and previously published ancillary spatial database. And the classification accuracy was calculated to be $92 \%$ for the whole area within the Heishui valley.

\section{Results}

In this study, hydrograph separation analysis during transitional period from low-flow to high-flow (Zhang et al., 2002) was conducted in different tributaries. The results showed that contribution of tributaries $A$ and $B$ to river $C$ was $60 \%$ and $40 \%$; contribution of tributaries $\mathrm{H}$ and $\mathrm{I}$ to river $\mathrm{J}$ was $88 \%$ and $12 \%$; contribution of tributaries $\mathrm{K}$ and and $62 \%$, respectively. The results also showed that contributions of tributaries $E, F$ and $\mathrm{D}$ to river $\mathrm{G}$ was $56 \%, 7 \%$, and $37 \%$, respectively (Table 1 ). The average runoff amount during 15 years (1990-2004) of the two hydrological monitor stations showed the contributions of $\mathrm{G}$ to $\mathrm{M}$ was $29 \%$ and $32 \%$, respectively in May and June, and that of the studying year was $30 \%$ and $34 \%$. The contribution was quite similar to the result $\left(74 \%{ }^{*} 38 \%=28 \%\right)$ from the stable isotope tracer.

Based on both the proportions of the tributaries to mixed sites and the mixed sites to the whole water, the contributions of tributaries $A, B, E, F, H, I$, and $\mathrm{K}$ to the whole river were computed, and the contribution of tributary $\mathrm{H}$ with $40.37 \%$ was maximal and that of tributary $\mathrm{F}(2.00 \%)$ was minimal (Table 2$)$. The order of contributions of surface and subsurface waters was the catchments $\mathrm{H}(29.87 \%), \mathrm{K}(24.18 \%), \mathrm{E}(11.30 \%), \mathrm{B}$ $(5.02 \%), I(3.86 \%), A(2.73 \%)$ and $F(1.40 \%)$, which was different from the order of contributions of the groundwater $\mathrm{H}(10.5 \%), \mathrm{E}(4.4 \%), \mathrm{K}(1.82 \%), \mathrm{I}(1.65 \%), \mathrm{A}(.1 .47 \%)$, $\mathrm{B}(1.18 \%), \mathrm{F}(0.60 \%)$.

HESSD

$3,1021-1043,2006$

Effects of vegetation patterns on yields of water

Y. Liu et al.

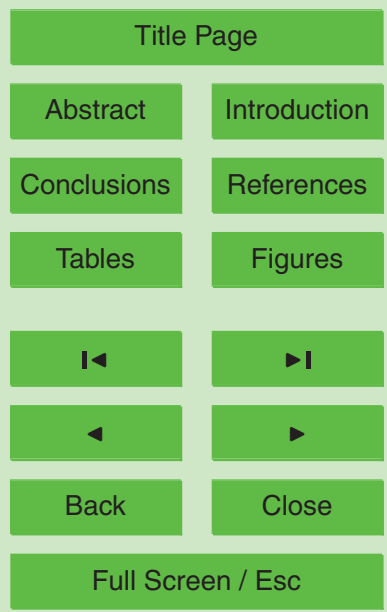

Printer-friendly Version

Interactive Discussion 
HESSD

In the Heishui valley the vegetations included deciduous broadleaved forests, mixed broadleaved and coniferous forests, subalpine coniferous forests, alpine shrub, alpine shrub meadow, alpine meadow and croplands (Fig. 4). At catchment scale, included A,

$5 \mathrm{~B}, \mathrm{E}, \mathrm{F}, \mathrm{H}, \mathrm{I}$ and $\mathrm{K}$ (Fig. 3), the results of vegetation classification showed that the total vegetation cover in catchments $\mathrm{F}, \mathrm{A}, \mathrm{I}, \mathrm{E}, \mathrm{B}, \mathrm{H}$ and $\mathrm{K}$ was $97.59 \%, 96.09 \%, 96.07 \%$, $95.93 \%, 94.18 \%, 92.05 \%$ and $86.64 \%$, respectively; the subalpine coniferous forest, alpine shrub and alpine meadow were the dominant vegetations and these occupied more than $80 \%$ of the land cover in any of the seven catchments,; the forest cover in 10 catchments I, A, F, K, B, H and E was, respectively, 43.12\%, 35.56\%, 32.99\%, 25.34\%, $23.23 \%, 20.56 \%$ and $19.58 \%$ (Table 3 ).

4.3 Effects of vegetation patterns on yields of the surface and subsurface waters during the level-flow period

Our results showed that there were contrary trends between vegetation, forest and sub15 alpine coniferous forest covers and surface \& subsurface waters; namely, high cover percentages were associated with low water yields and low cover percentages implied high water contributions (Figs. 5a, b, c); It was also obvious that the percentages of surface and subsurface waters increased with the percentage of alpine shrub and alpine meadow increasing, respectively (Figs. $5 d$, e). But the relationships of mentions above

were presented in two modes including $\mathrm{H}-\mathrm{K}-\mathrm{I}$ and E/B-F/A except for (Fig. 5a) and the two modes implied the differences in altitude (Fig. 2). The effects of low altitude vegetations along the line $\mathrm{H}-\mathrm{K}-\mathrm{I}$ on water yield were more strongly than that of high altitude vegetations along the line E/B-F/A. Therefore, the vegetation patterns could affect the runoff amount at catchment scales during transitional period from low-flow to
3, 1021-1043, 2006

\section{Effects of vegetation patterns on yields of water \\ Y. Liu et al.}

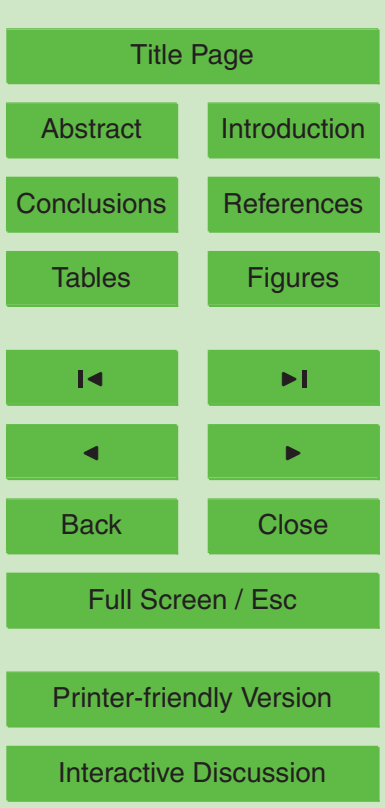

EGU 


\section{Discussion}

Land cover is the key parameter in hydrological cycle (Giertz et al., 2005) and water yield is an important indicator of water balance at large watershed scale (Smith, 1990). Meanwhile, ecosystem water exchanges, including evaporation, transpiration, 5 soil moisture movement, groundwater movement and runoff, determine the formation, distribution and variability of ecosystems (Wang et al., 2005). Thus the relationships between land cover and water yield are an important issue in ecological studies.

In this study, there was a special phenomenon, altitude modes, occurring in the effects of vegetation patterns on the water yield. According to the T-test of mean and min altitudes, respectively, it was obvious that there was significant difference $(p<0.05)$ between group including $B, E, F$ and $A$ catchments and group including $\mathrm{H}, \mathrm{K}$ and $\mathrm{I}$ catchments (Figs. 2 and 3), which was same with the two modes in Fig. 5. This showed that there were two water yield patterns in the Heishui Valley, which were low altitude pattern and high altitude pattern. Because altitude variations could lead to temperature

ariations in alpine valley, there was relatively higher temperature in the low altitude pattern than that in the high altitude pattern. High temperature caused higher melt water velocity in the low altitude pattern, while topography controlled the spatial patterns of water, soil water properties and soil moisture (Ambroise, 1995). So the effects of low altitude vegetation along the line $\mathrm{H}-\mathrm{K}-\mathrm{I}$ on water yield were stronger than that of high altitude vegetation along the line $\mathrm{E} / \mathrm{B}-\mathrm{F} / \mathrm{A}$.

We also found that the increasing in the alpine shrub cover caused increasing of the water yield and the similar correlation between the alpine meadow cover and the water yield, which was contradicted with reduction in shrub and meadow leads to increasing of water yield in the paired catchments (Bosch and Hewlett, 1982; Sahin and Hall, 1996). The main reason was the capacity of water retention by terrestrial ecosystem during transitional period from low-flow to high-flow. Many results have indicated that the capacity of water retention is closely related to vegetation, soil and slope (Lee, 1980; Hewlett, 1982; Ma, 1993; Guo and Gan, 2002). In the Heishui Valley, because
HESSD

3, 1021-1043, 2006

Effects of vegetation patterns on yields of water

Y. Liu et al.

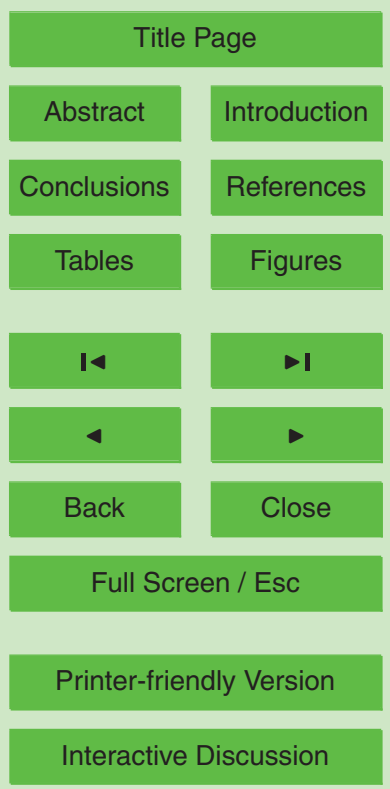

EGU 
subalpine coniferous forests had more power in increasing the soil organic matter, improving the soil construction, receding soil bulk density and enhancing the soil porosity than the alpine shrubs and meadows (Chang et al., 2003), the soil of subalpine coniferous forests had the highest water holding capability. Meanwhile, the velocity of melting 5 water, mainly including snow and soil water meltings (Zhang et al., 2002), in the southfacing slopes was higher than those in the north-facing slopes during transitional period from low-flow to high-flow, and the subalpine coniferous forests mainly distributed in the north-facing slopes, the alpine shrubs dominated the south-facing slopes and the alpine meadows common on the top of the mountains (Sichuan Vegetation Editing 10 Committee, 1980; Jiang et al, 2004), So the water yield was positive correlation with vegetation cover patterns in the south-facing slopes and negative correlation with the forest cover in the north-facing slopes.

Although spatial heterogeneity is omnipresent, changes with different scales, and the scaling is very difficult (Wu, 2000), scale analysis plays a more and more important role in landscape hydrology and forest studies (Dietrich and Montgomery, 1998) and the relationships between vegetation cover and water yield in relative small catchments are needed to scale to larger catchments (Brown, et al., 2005). In this experiment, we could find that with the areas of seven catchments varying from $222 \mathrm{~km}^{2}$ to $2248 \mathrm{~km}^{2}$, there was an obvious trend that the yields of surface and subsurface waters decreased with the increasing of vegetation cover, forest cover and subalpine coniferous forest, respectively. At the same study areas, Jiang et al. (2004) believed that the increasing of the total vegetation cover decreased annual runoff amount, while the relationship between forest cover and annual runoff was irregular in the Minjiang' catchments at different scales from $2338 \mathrm{~km}^{2}$ to $7621 \mathrm{~km}^{2}$. But in small scale $\left(<2 \mathrm{~km}^{2}\right)$, results of paired catchment studies showed that the reduction in forest cover or coniferous forest cover increased water yields (Hibbert, 1967; Bosch and Hewlett, 1982; Sahin and Hall, 1996; Brown et al., 2004). Based on the researches in the three different scales, the forest cover, especially alpine coniferous forest cover, played different roles in controlling the water yields. In middle to small scale $\left(<2248\right.$ or $\left.<2 \mathrm{~km}^{2}\right)$, the forest cover played impor-
HESSD

3, 1021-1043, 2006

Effects of vegetation patterns on yields of water

Y. Liu et al.

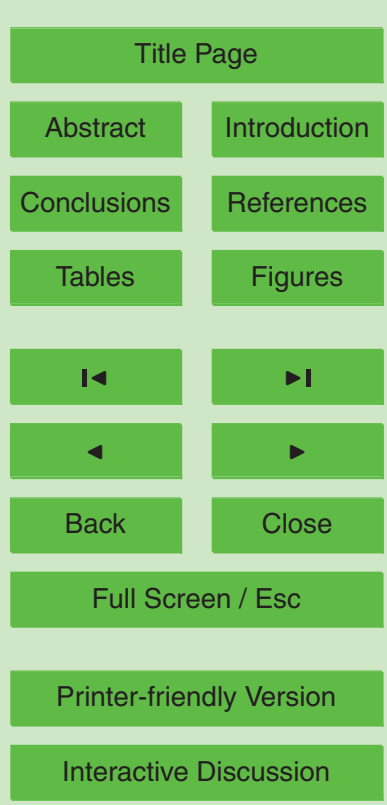

EGU 
tant controlling in water yields, while at large scale $\left(>2338 \mathrm{~km}^{2}\right)$ the controlling function was irregular and weak. The interaction in middle or small scales could not be scaled to the large scale. On the contrary, it was obvious that increasing in the whole vegetation cover could cause the reduction of the water yields even from small scale to large 5 scale. The possible reason was that the factors affecting water yield were complex in large scale, and the relationships between the whole vegetation cover and water yields could better reflect the complexity than that between subalpine coniferous forest and the water yields did at large scale.

\section{Conclusions}

10 In the Heishui Valley, spatial variations of vegetation types in different watersheds affected the water yield during transitional period from low-flow to high-flow. The reduction in the total vegetation, forest and subalpine coniferous forest covers could cause increasing in water yield, while water yield increased with the alpine shrub and meadow cover increasing, respectively. The trends were displayed in low altitude pattern and 15 high altitude pattern. The main reasons of the phenomenon were the different intrinsic vegetation characteristics and topographies. At large scale the total vegetation cover played the most important effect on water yield, while one type of vegetation such as coniferous forest cover would mostly affect the water yield at relatively small scale.

Acknowledgements. This study was supported by The National Key Basic Research Special 20 Funds (NKBRSF), PR China (No.2002CB111504). The authors would like to thank Y. H. Xie, S. T. Zhang and J. W. Zheng, J. H. Jiang, Y. Zhang, G. J. Ren and X. Yao for their generous and ungrudging assistance during the experimental process. Many thanks also to the employees of the Heishui Weather Bureau for supplying necessary meteorological data. We also thank Y. S. Huang and J. Y. Pan of the Earth Sciences Department of Nanjing University for his advice and help.

\section{HESSD}

3, 1021-1043, 2006

Effects of vegetation patterns on yields of water

Y. Liu et al.

Title Page

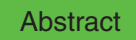

Introduction

Conclusions

Tables

References

Figures

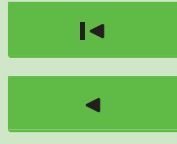

$\rightarrow$

Back

Close

Full Screen / Esc

Printer-friendly Version

Interactive Discussion 


\section{References}

Ambroise, B.: Topography and the water cycle in a temperate middle mountain environment: the need for interdisciplinary experiments, Agric. Forest Meteorol., 73, 217-235, 1995.

Andreassian, V.: Waters and forests: from historical controversy to scientific debate, J. Hydrol., 5 291, 1-27, 2004.

Barrent, E. C. and Curtis, L. F.: Introduction to environmental remote sensing, 4th ed. Stanley Thornes (Publishers) Ltd., London, UK, 452 pp, 1999.

Brown, A. E., Zhang, L., McMahon, T. A., Western, A. W., and Vertessy, R. A.: A review of paired catchment studies for determining changes in water yield resulting from alterations in 10 vegetation, J. Hydrol., 310, 28-61, 2005.

Bosch, J. M. and Hewlett, J. D.: A review of catchment experiments to determine the effect of vegetation changes on water yield and evapotranspiration, J. Hydrol., 55(1/4), 3-23, 1982.

Chang, M. T.: Forest hydrology: an introduction to water and forests, CRC Press, Boca Raton, Fla, 373 pp, 2003.

Chang, Z. H., Lu. Z. H., and Guan, W. B.: Water holding effect of subalpine dark coniferous forest soil in Gongga Mountain, China, J. Forestry Res., 14(3), 205-209, 2003.

Chen, Z.: The strategic position and the ecological and environmental function of the upper reaches of the Yangtze River, J. Mountain Sci., 18(3), 258-262, 2000.

Chen, N. S. and Chen, Q. B.: Frequency of different scale debris flows in limited triggering earth - Taking Luojiaba Valley debris flow for example, J. Chengdu Univ. Technology, 30, 612-616, 2003.

Dietrich, W. E. and Montgomery, D. R.: Hillslopes, channels, and landscape scale, in: Scale dependence and scale invariance in hydrology, edited by: Sposito, G., Cambridge University Press, New York, 30-60, 1998.

Giertz, S., Junge, B., and Diekkruger, B.: Assessing the effects of land use change on soil physical properties and hydrological processes in the sub-humid tropical environment of West Africa, Phys. Chem. Earth, 30, 485-496, 2005.

Guo, Z. W. and Gan, Y. L.: Ecosystem function for water retention and forest ecosystem conservation in a watershed of the Yangtze River, Biodiversity and Conservation, 11, 599-614, 2002.

Hewlett, J. D.: Principles of Forest Hydrology, University of Georgia Press, Athens, GA, 1982.

Hibbert, A. R.: Forest Treatment effects on water yield, Reprint from Proceedings of International Symposium on Forest Hydrology, Penn State University, 527-543, Pergamon Press,

1033
HESSD

3, 1021-1043, 2006

Effects of vegetation patterns on yields of water

Y. Liu et al.

Title Page

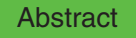

Introduction

Conclusions

References

Tables

Figures

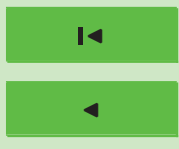

$\rightarrow$

Back

Close

Full Screen / Esc

Printer-friendly Version

Interactive Discussion 
New York, 1967.

Jiang, H.: Dca ordination,quantitative classification and environmental interpretation of spruce and fir communities in northwest Sichuan and Gansu, Acta Phytoecologica Sinica, 18, 297305, 1994.

5 Jiang, H., Liu, S. R., Sun, P. S., An S. Q., Zhou, G. Y., Li, C. Y., Wang, J. X., Yu, H., and Tian, $X$. J.: The influence of vegetation type on the hydrological process at the landscape scale, Can. J. Remote Sensing, 30(5), 743-763, 2004.

Kendall: Impact of isotope heterogeneity in shallow systems on shallow system on stormflow generation, Ph. D. dissertation, University of Maryland, College Park, pp 310, 1993.

10 Lee, R.: Forest Hydrolog, Columbia University Press, New York,1980.

Leopoldo, P. R., Martinez, J. C., Mortatti, J.: Runoff hydrograph analysis in agricultural watersheds by oxygen-18, in: Isotope techniques in water resources development, IAEA, Vienna, 539-550, 1987.

Li, A. N., Zhou, W. C., and Jiang, X. B.: Dynamic change of land use/land cover during15 years 15 in upper reaches of Minjiang River supported by RS and GIS, Journal of Soil And Water Conservation, 17, 153-156, 2003.

Lillesand, T. M., and Kiefer, R. W.: Remote sensing and image interpretation, 4th ed, John Wiley \& Sons, Inc., New York, pp 725, 2000.

Liu, S. R., Sun, P. S., Wang, J. X., and Chen, L. W.: Hydrological functions of forest vegetation in the upper reaches of the Yangtze River, J. Nat. Resour., 16(5), 451-456, 2001.

Ma, X.: Forest Hydrology, Chinese Forestry Press, Beijing, 1993.

McDonnell, J. J., Stewart, M. K., and Owens, I. F.: Effect of catchment-scale subsurface mixing on stream isotopic response, Water Resour. Res., 27, 3065-3073, 1991.

Mortathi, J., Moraes, J. M., Rodrigues, J. C., Victoria, R. L., and Martinelli, L. A.: Hydrograph separation of the Amazon River using 180 as an isotopic tracer, Scientia Agricola, 54(3), 167-173, 1997.

Pu, F. D.: The present conditions of ecology and biodiversity protection at upstreams of Minjiang, Resour. Sci., 22, 83-85, 2000.

Phillips, D. L. and Gregg, J. W.: Source partitioning using stable isotopes: coping with too many sources, Oecologia, 136, 261-269, 2003.

Pinder, G. F. and Jones, J. F.: Determination of the groundwater component of peak discharge from the chemistry of total runoff, Water Resour. Res., 5(2), 438-445, 1969.

Post David, A. and Jones Julia, A.: Hydrologic regime of forested, mountainous, headwater
HESSD

3, 1021-1043, 2006

Effects of vegetation patterns on yields of water

Y. Liu et al.

Title Page

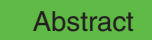

Conclusions

Tables

Figures

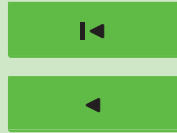

Back

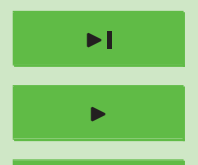

Close

Full Screen / Esc

Printer-friendly Version

Interactive Discussion 
basin in New Hampshair, North Carolina, Oregon, and Puerto Rico, Adv. Water Resour., 24, 1195-1210, 2001.

Sahin, V. and Hall, M. J.: The effects of afforestation and deforestation on water yields, J. Hydrol., 178(1/4), 293-309, 1996.

5 Sichuan Vegetation Editing Committee: Sichuan vegetation, The People's Publisher of Sichuan, Chengdu, China, pp 465, 1980.

Smith, R. L.: Ecology and field biology, 4th ed, Harper Collins College Publishers, New York, pp 1055, 1990.

Wang, G. X., Shen, Y. P., Qian, J., and Wang, J. D.: Study on the Influence of Vegetation Change on Soil Moisture Cycle in Alpine Meadow, J. Glaciology and Geocryology, 25(6), 653-659, 2003.

Wang, Q. X., Watanabe, M., and Ouyang, Z.: Simulation of water and carbon fluxes using BIOME-BGC model over crops in China, Agric. Forest Meteorol., 131, 209-224, 2005.

Wang, Z. W.: Exploitation of water and power of Heishui Valley, Sichuan Water Power, 22, 4-6, 2003.

Wu, J. G.: Landscape ecology (1st edn), Higher Education Press, Beijing, 2000.

Zhang, W. J., Li, M., Wu, Z. G., and Yang, B. G.: Features and evaluation of glacial landscape resources in Heishui Coutry, Sichuan Province, J. Mountain Sci., 20, 461-465, 2002.

Zhuang, P., Pen, Q. X., Liu, R. Y., and Wu, H.: Study on the decline state of the abies fabri forest in Emei Mountain, J. Wuhan Botanical Res., 13, 317-328, 1995.

Zhang, Z. Q., Zhao, Y. T., and Yu, X. X.: Hydrological processes of a dark coniferous forested watershed in the upper reaches of Yangtze River, J. Beijing Forestry Univ., 24(5/6), 25-30, 2002.

\section{HESSD}

3, 1021-1043, 2006

Effects of vegetation patterns on yields of water

Y. Liu et al.

Title Page

Abstract

Introduction

Conclusions

References

Tables

Figures

14

4

Back

Full Screen / Esc

Printer-friendly Version

Interactive Discussion 


\section{HESSD}

3, 1021-1043, 2006

\section{Effects of vegetation} patterns on yields of water

Y. Liu et al.

Table 1. Contribution of the tributaries to the main river course in Heishui Valley, Western Sichuan, China.

\begin{tabular}{|c|c|c|c|c|c|c|c|c|c|c|c|}
\hline \multirow{2}{*}{$\begin{array}{l}\text { Mixed sites } \\
\text { Contribution sites }\end{array}$} & \multicolumn{2}{|c|}{ (C) } & \multicolumn{3}{|c|}{ (G) } & \multicolumn{2}{|c|}{ (J) } & \multicolumn{2}{|c|}{ (M) } & \multicolumn{2}{|c|}{ (L) } \\
\hline & A & B & $\mathrm{E}$ & $D$ & $\mathrm{~F}$ & $\mathrm{H}$ & 1 & $\mathrm{~K}$ & $\mathrm{~L}$ & G & $\mathrm{J}$ \\
\hline$\delta \mathrm{D}$ of mixed sites $(\% \circ)$ & \multicolumn{2}{|c|}{-91} & \multicolumn{3}{|c|}{-90.5} & \multicolumn{2}{|c|}{-87.8} & \multicolumn{2}{|c|}{-86.1} & \multicolumn{2}{|c|}{-88.8} \\
\hline$\delta \mathrm{D}$ of contribution sites $(\% \circ)$ & -90.8 & -91.3 & -91.5 & -89.4 & -88.5 & -88.1 & -85.7 & -78.4 & -88.8 & -90.5 & -87.8 \\
\hline Contribution (\%) & 60 & 40 & 56 & 37 & 7 & 88 & 12 & 26 & 74 & 38 & 62 \\
\hline
\end{tabular}

* Note: the A, B, C, D, E, F, H, I, K, L, G and J denote the different tributaties; The (C), (G), (J), $(\mathrm{M}),(\mathrm{L})$ denote the mixed sites of different tributaries; the contributions of different tributaries are versus the mixed sites such as (C), (G), (J), (M) and (L).

Title Page

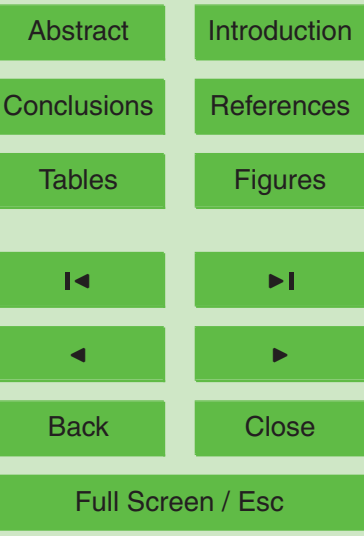

Printer-friendly Version

Interactive Discussion 


\section{HESSD}

3, 1021-1043, 2006

Effects of vegetation patterns on yields of water

Table 2. Contributions of water sources to the whole river water in the seven watersheds, Western Sichuan, China.

\begin{tabular}{lccccccc}
\hline Sites & $\mathrm{A}$ & $\mathrm{B}$ & $\mathrm{E}$ & $\mathrm{F}$ & $\mathrm{H}$ & $\mathrm{I}$ & $\mathrm{K}$ \\
\hline $\begin{array}{l}\text { Contribution of groundwater (\%o) } \\
\begin{array}{l}\text { Contributionof surface and } \\
\text { subsurface waters (\%) }\end{array}\end{array}$ & 1.47 & 1.18 & 4.4 & 0.60 & 10.5 & 1.65 & 1.82 \\
$\begin{array}{l}\text { Contributionof tributaty water } \\
\text { to the whole water (Total)(\%) }\end{array}$ & 2.73 & 5.02 & 11.30 & 1.40 & 29.87 & 3.86 & 24.18 \\
\end{tabular}

* Note: The contributions of different waters in this tabulation were relative to the whole water, the water in any tributary was composed of groundwater, surface and subsurface waters. Sum of the contributions of seven tributary waters were equal to 100 .

Y. Liu et al.

Title Page

Abstract

Conclusions

Tables

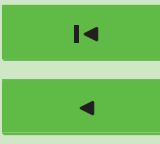

Back
Introduction

References

Figures

I

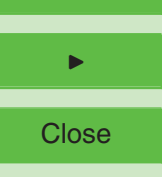

Full Screen / Esc

Printer-friendly Version

Interactive Discussion 


\section{HESSD}

3, 1021-1043, 2006

Effects of vegetation patterns on yields of water

Table 3. Vegetation distribution (land area in $\mathrm{km}^{2}$ ) in the seven basins in the Heishui Valley, Western Sichuan, China.

\begin{tabular}{|c|c|c|c|c|c|c|c|}
\hline \multirow{2}{*}{ Land cover types } & \multicolumn{7}{|c|}{ Catchment $\left(\mathrm{km}^{2}\right)$} \\
\hline & A & $\mathrm{B}$ & E & $\mathrm{F}$ & $\mathrm{H}$ & I & $\mathrm{K}$ \\
\hline Subalpine Coniferous forest & 109.4(35.33) & $51.5(23.23)$ & $99.4(16.48) 29.1(25)$ & $403.8(17.96)$ & $248.7(41.61)$ & 161.6(21.12) & \\
\hline Deciduous broadleaved forest & $0(0.00)$ & $0(0.00)$ & $0.4(0.07)$ & $2.1(1.80)$ & $42.9(1.91)$ & $0.1(0.02)$ & 28.31(3.7) \\
\hline $\begin{array}{l}\text { Mixed Broadleaved and } \\
\text { coniferous forest }\end{array}$ & $0.7(0.23)$ & $0(0.00)$ & $18.3(3.03)$ & $7.2(6.19)$ & $15.4(0.69)$ & $8.9(1.49)$ & $4.0(0.52)$ \\
\hline Alpine shrub & $32.2(10.4)$ & $26.8(12.09)$ & $78.2(12.97)$ & $13.4(11.51)$ & $358(15.93)$ & $62.9(10.52)$ & $119.5(15.62)$ \\
\hline Alpine meadow & $136.5(44.09)$ & $117.3(52.91)$ & $341.7(56.67)$ & $50.8(43.64)$ & $1080.9(48.08)$ & 198.5(33.21) & $308.9(40.36)$ \\
\hline Alpine shrub meadow & $18.7(6.04)$ & $13.2(5.95)$ & $40.9(6.78)$ & 13.1(11.25) & $15.4(0.69)$ & $55.2(9.24)$ & $40.7(5.32)$ \\
\hline Cropland & $10.1(3.26)$ & $0.5(0.23)$ & $2.2(0.36)$ & $0.3(0.26)$ & $35.3(1.57)$ & $15.6(2.61)$ & $45.2(5.91)$ \\
\hline Slash land & $0(0.00)$ & $0(0.00)$ & $1.2(0.19)$ & $0.4(0.34)$ & $18.5(0.82)$ & $0.5(0.08)$ & $0(0.00)$ \\
\hline Barren land & $1.3(0.42)$ & $7.1(3.2)$ & $12.3(2.04)$ & $0(0.00)$ & $75.1(3.34)$ & $4.5(0.75)$ & $56.4(7.37)$ \\
\hline Water body & $0(0.00)$ & $1.5(0.68)$ & $1.8(0.29)$ & $0.01(0.01)$ & $3.3(0.14)$ & $0.3(0.05)$ & $0.5(0.07)$ \\
\hline Glacier & $0.7(0.23)$ & $3.8(1.71)$ & $7.1(1.18)$ & $0(0.00)$ & $3.8(0.16)$ & $0(0.00)$ & $0(0.00)$ \\
\hline Arid shrub & 0 & 0 & 0 & 0 & 0 & 0 & 0 \\
\hline Total & $309.6(100)$ & $221.7(100)$ & $603.5(100)$ & $116.41(100)$ & $2248.8(100)$ & $597.7(100)$ & $765.2(100)$ \\
\hline
\end{tabular}

*Note: The arid shrub didn't exist in the seven catchments and existed in other catchments in this study.

\section{Y. Liu et al.}

Title Page

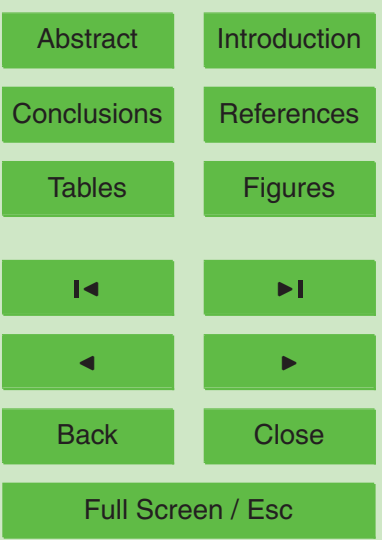

Printer-friendly Version

Interactive Discussion 


\section{HESSD}

3, 1021-1043, 2006

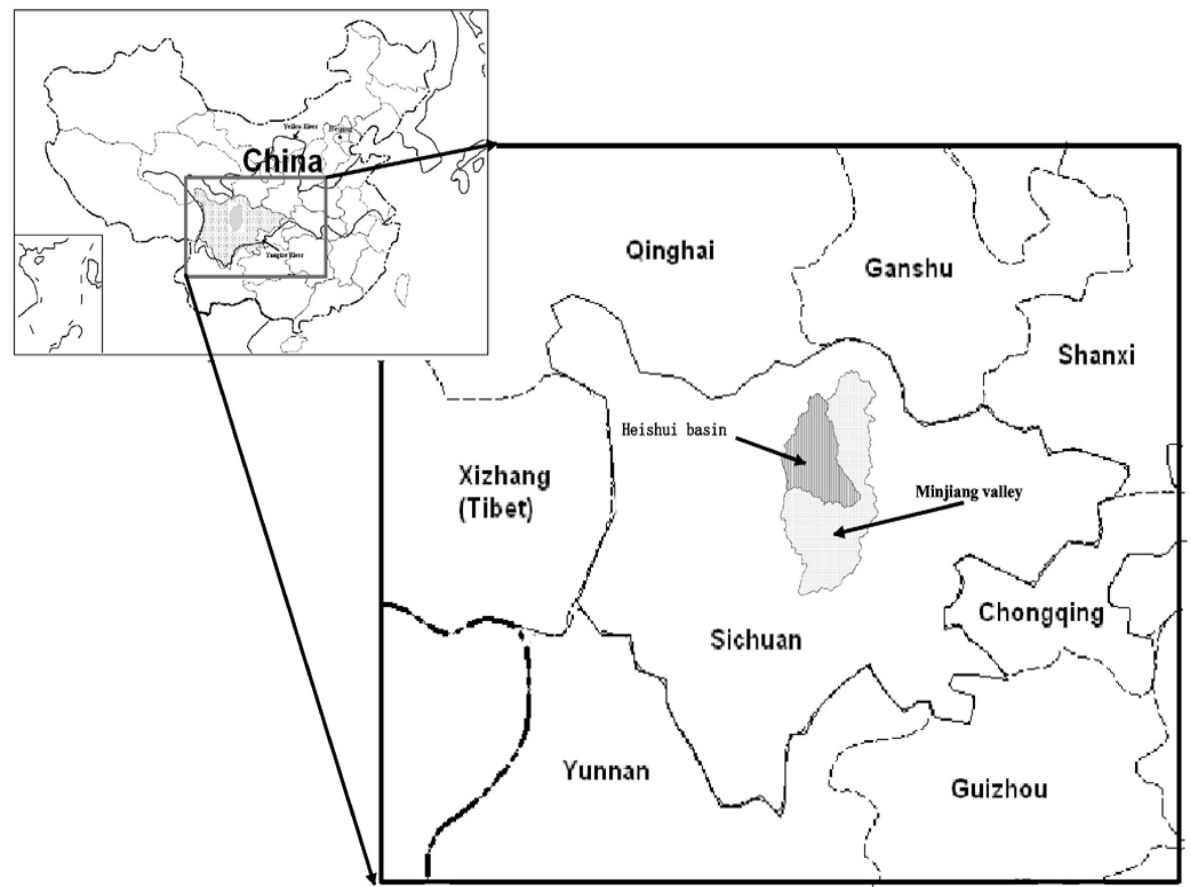

\section{Effects of vegetation} patterns on yields of water

Y. Liu et al.

Title Page

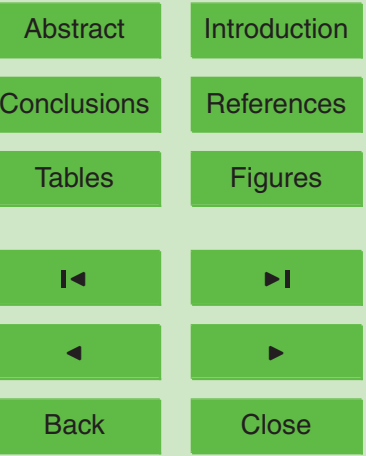

Full Screen / Esc

Fig. 1. Location of the Heishui valley in northwest Sichuan, China.

Printer-friendly Version

Interactive Discussion 


\section{HESSD}

3, 1021-1043, 2006

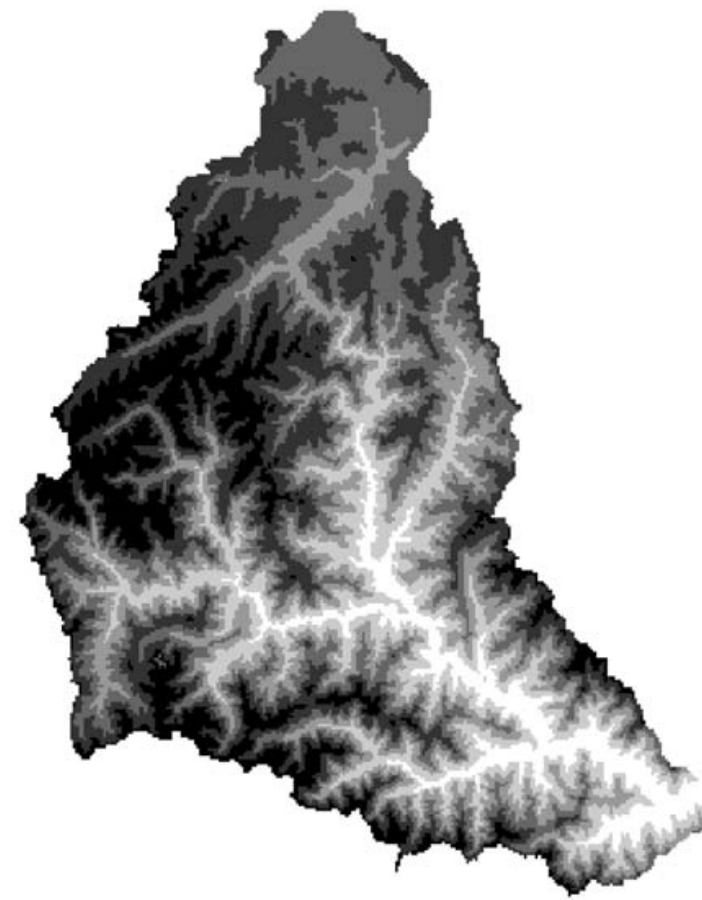

\section{Legend}

Elevation (m)

$\square$ 1,800 - 2, 550

$2,550-3,100$

$3,100-3,500$

$3,500-3,900$

$3,900-4,300$

$4,300-5,200$

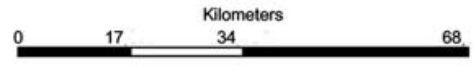

Fig. 2. DEM in the Heishui Valley, Western Sichuan, China.

\section{Effects of vegetation} patterns on yields of water

Y. Liu et al.

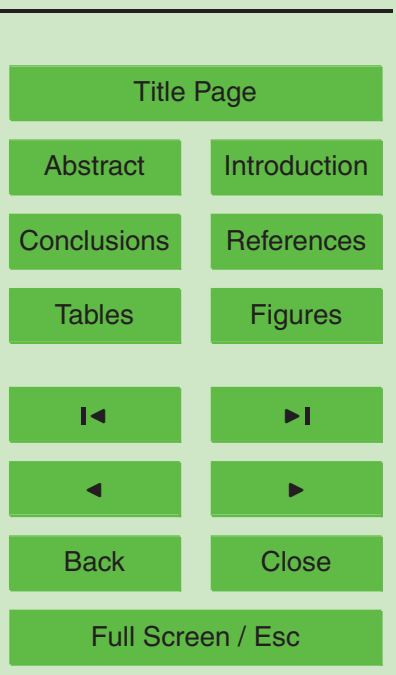

Printer-friendly Version

Interactive Discussion 


\section{HESSD}

3, 1021-1043, 2006

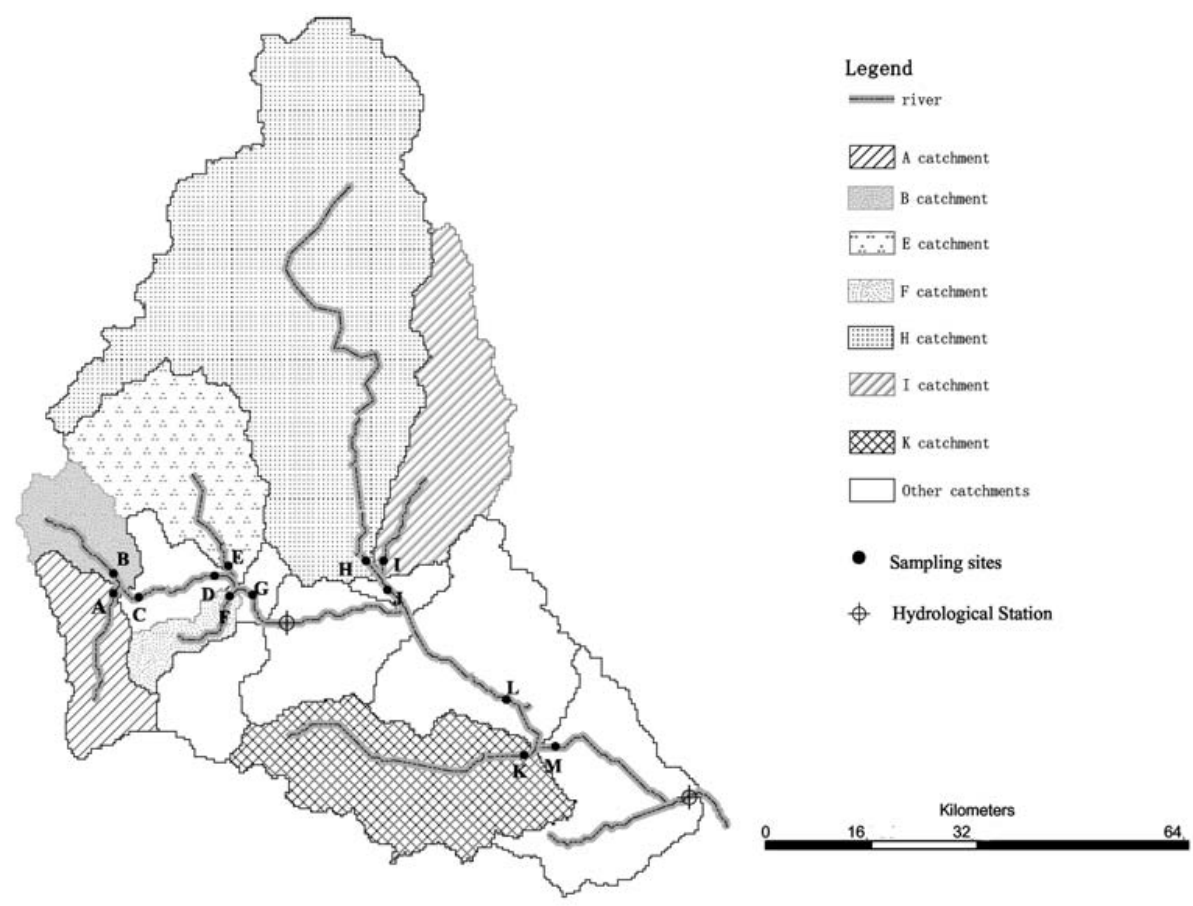

Effects of vegetation patterns on yields of water

Y. Liu et al.

Title Page

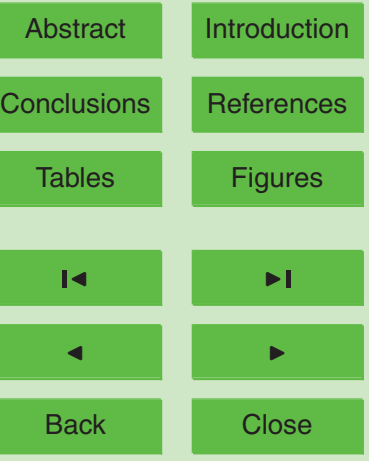

Full Screen / Esc

Printer-friendly Version

Interactive Discussion 


\section{HESSD}

3, 1021-1043, 2006

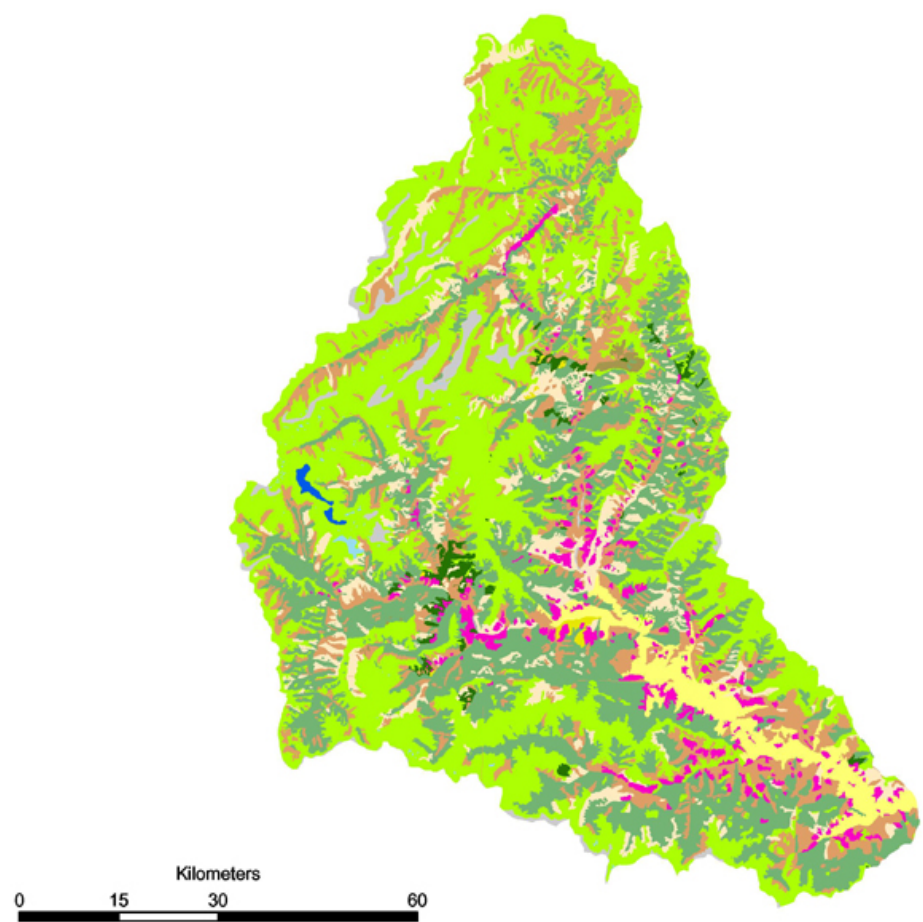

\section{Legends}

Deciduous broadleaved forest

Mixed Broadleaved and coniferous forest

Subalpine Coniferous forest

Arid shrub

Alpine shrub

Alpine meadox

Alpine shrub meadom

Cropland

Slash land

Barren land

water bod

glacier

Fig. 4. Vegetation types and distribution in the Heishui Valley Western Sichuan, China, based on Landsat TM satellite imagery.

\section{Effects of vegetation} patterns on yields of water

Y. Liu et al.

Title Page

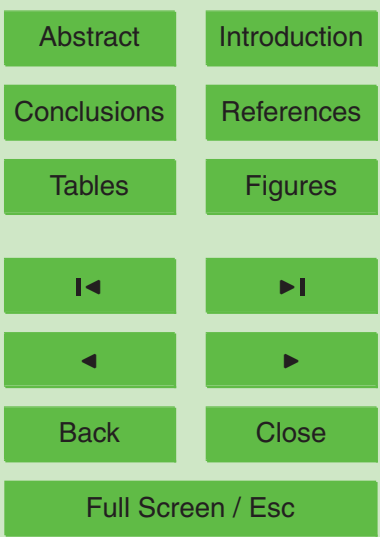

Printer-friendly Version

Interactive Discussion 


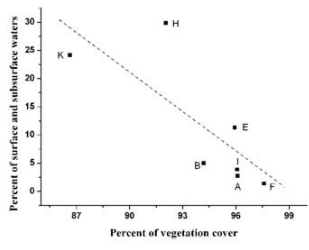

(a)

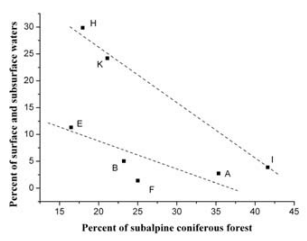

(c)

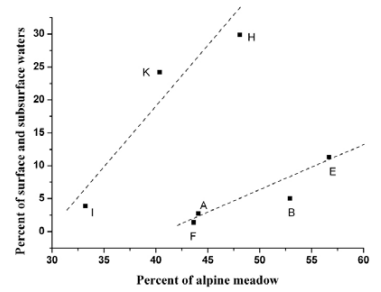

(e)

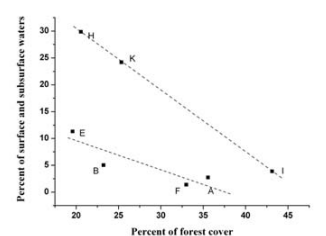

(b)

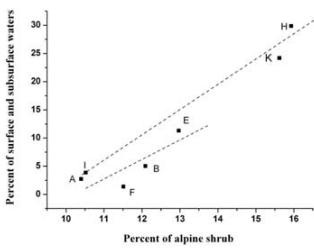

(d)
HESSD

3, 1021-1043, 2006

Effects of vegetation patterns on yields of water

Y. Liu et al.

Title Page

Abstract

Introduction

Conclusions

References

Tables

Figures

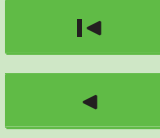

Back

Close

Fig. 5. Relationships between vegetation cover patterns and the yields of surface \& subsurFull Screen / Esc face waters in two modes including $\mathrm{H}-\mathrm{K}-\mathrm{I}$ and $\mathrm{E} / \mathrm{B}-\mathrm{F} / \mathrm{A}$ in the seven catchments of the Heishui valley during transitional period from low-flow to high-flow. (a) total vegetation covers versus surface \& subsurface waters, (b) forest cover versus surface \& subsurface waters, (c) subalpine coniferous forest versus surface \& subsurface waters, (d) alpine shrub versus surface \& subsurface waters and (e) alpine meadow versus surface \& subsurface waters. 